\title{
Automated metric profiling and comparison of Ancient Greek verse epics in Hexameter
}

\author{
Oliver Schoisswohl (Vienna) and Evangelos C. Papakitsos (West Attica)
}

\begin{abstract}
This article describes a software tool, named Dactylo, which is capable of performing metrical analysis, alias scansion, of epics written in hexameter. The automated scansion is based on wellknown scanning rules of various theoretical works. The development methodology introduces the concept of computerized metric profiling and metric distance, which is a measurement value that reflects the degree of similarity or dissimilarity between different epics. For this purpose, eight renowned epics have been scanned, including Iliad and Odyssey, with plenty of statistical information. Based on these outcomes, these epics can be classified in groups that reflect very well the three periods of their creation, namely Classical, Hellenistic and Late Antiquity. Dactylo demonstrates its ability to produce statistics for hexameter's metric patterns in a massive scale, easily and accurately, becoming so a contribution of Computational Linguistics to the diachronic comparative and quantitative language studies.
\end{abstract}

\section{$1 \quad$ Introduction}

The topic of this article is the computer supported metric profiling and comparison of verse epics in ancient Greek language, written in hexameter, regarding their syllabic distribution. Renowned epics of this category are Iliad and Odyssey (cf. Homer s. a.), Theogony (cf. Hesiod s. a.), Argonautica (cf. Apollonius Rhodius s. a.) and others. All of these poems are written in hexameter, the metric scheme of classical Greek and Latin verse epics that determines the prosodic structure of their verses (cf. Halporn/Ostwald/Rosenmeyer 1980). Namely, this scheme imposes a specific sequence of long and short syllables onto each of the verses, which are arranged in groups that are called "feet". The term originates in the rehearsals of the ancient Greek theatre (cf. Seale 1830), where a person beat time by striking his foot on the ground, according to the rhythmic structure of the poem that is called metre. The metre was selected depending on the two main types of verse: the stichic (like hexameter), which seems to have been recited, or the lyric, which seems to have been sung (cf. Raven 1962). In the case of hexameter, the number of feet per verse denotes the metre of the poem/verse (in other categories of poetry, the scheme is more composite). In this respect, a poem written in hexameter is composed of six feet per verse, each consisting either of two long syllables (long-long), named spondee, or one long and two short (long-short-short), named dactyl (cf. Maas 1962). Thus in hexameter, the actor recited two or three syllables (either a spondee or a dactyl) for every stroke of the foot. 
Various principles of metrical syllabification are present in ancient Indo-European poetry, as indicated by the comparison of ancient Greek, Iranian, Latin, Sanskrit, Celtic and Slavic verses (cf. West 1982). Consequently, the study of the various rhythmic structures is a significant topic of classical literature (cf. Laan 1995), including the hexameter (cf. Edwards 1986). A key-activity of the relevant quantitative research is the statistical analysis of the poems and their comparison. For example, in the case of Homeric hexameter, it has been reported that a dactyl is placed $95 \%$ at the fifth foot, while the second foot is the least possible place (cf. Papakitsos 2011). Accordingly, the development of computerized tools, like the one presented herein, aims to become a valuable assistance to scholars for saving labour and time.

\section{Theoretical framework}

In modern poetry, the rhythm is mainly measured by the varying stress/accent on syllables. Namely, an unaccented syllable is short while an accented one is long (cf. Raven 1962). In ancient Greek and Latin poetry though, the rhythm was based on the quantity of syllables, instead of accent (cf. Halporn/Ostwald/Rosenmeyer 1980). The process of determining the metric pattern (or scheme) is called scanning or scansion. Scanning a verse to find its underlying metric pattern is driven by a set of scanning rules (cf. Annis 2006). The rules regarding feet identification are built into the presented software application, named Dactylo. These rules are summarized in Table 1. Words are internally transformed, by means of an auto-adjustment process, in order to facilitate the computerized process.

Other, more complex and/or more specialized rules do exist (cf. Papakitsos 2011). The table of auto-adjustments for analysis is far from complete and currently captures only a small subset of particular phenomena encountered (e. g., contraction). Nevertheless, in the current first iteration of the Dactylo project, a resolution rate of $95 \%$ to $99 \%$ for the epics scanned delivers a broad enough statistical base for the aggregation of statistical information (see below section: 4. Results and Discussion), such that the developer postpones a refinement of implemented rules, for future iterations of the project.

\subsection{Related works}

The computerized scansion of hexameter is relatively old, starting with Latin poetry (cf. Ott 1973). These computational efforts were confined neither only to Latin poetry (cf. Mayrhofer 1987) nor to hexameter (cf. Jong and Laan 1996). Some of them may focus on encoding for representing quantitative metrical analyses (cf. Mahoney 2003) or on comparative statistical approaches to rhythmic patterns between poems of different eras (cf. Eder 2007).

The first known computerized system, dedicated to the automated scansion of ancient Greek hexameter, had been implemented in Ada programming language by E. Papakitsos (1992). Its scanning algorithm was based on the statistical distribution of dactyls per verse in Homeric poetry, as defined in theoretical works. The original version could not directly support a Greek keyboard; therefore the second version was implemented in Turbo-Pascal 6 programming language (cf. Papakitsos 2000). Along with the advancement of graphical user interfaces through object-oriented programming, the third version has been implemented in Visual Basic 6.0 programming language (cf. Papakitsos 2009) for corresponding to technological advancements. Mainly targeted to support academic education in the Departments of Classics, the fourth and 
last version is implemented in C\# programming language (cf. Foti 2013). The same scanning algorithm has been used in another software tool, for exploring the influence of the Pythagorean theories to the structuring of Plato's works (cf. Tsoumaki 2012; Papakitsos and Tsoumaki 2013), after the theoretical and computational work of J. Kennedy $(2010 ; 2011)$ and by his request. Finally, this system can neither support the direct automated handling of complex phonological phenomena, like synizesis, nor it produces statistical reports that would facilitate comparisons of metrical profiles between different poems.

\begin{tabular}{|c|c|c|c|}
\hline Rule group & Object & $\begin{array}{l}\text { Value and } \\
\text { scan }\end{array}$ & Details and comments \\
\hline \multirow[t]{5}{*}{ vowel length } & $\eta \omega$ & long & \\
\hline & diphthongs/digraphs & long & \\
\hline & $\varepsilon 0$ & short & \\
\hline & $\alpha \imath v$ & short or long & $\begin{array}{l}\text { dichronae, i. e., can be short or } \\
\text { long }\end{array}$ \\
\hline & any with $\sim$ & long & \\
\hline \multirow[t]{8}{*}{ syllable quantity } & long vowels & long & \\
\hline & short vowels & short & \\
\hline & $\begin{array}{l}\text { long vowels at end } \\
\text { of word, next word } \\
\text { starts with vowel }\end{array}$ & anceps & known as epic correption \\
\hline & $\begin{array}{l}\text { any vowel followed } \\
\text { by } 2 \text { or more conso- } \\
\text { nants (except below) }\end{array}$ & long & \\
\hline & $\begin{array}{l}\text { short or anceps vow- } \\
\text { els followed by ex- } \\
\text { actly } 2 \text { consonants of } \\
\text { type plosive fol- } \\
\text { lowed by sonans in } \\
\text { the same word } \\
\text { (except below) }\end{array}$ & anceps & $\begin{array}{l}\text { includes pairs of any of } \\
\delta \tau \theta \beta \pi \varphi \gamma \kappa \chi \\
\text { followed by any of } \\
\lambda \mu \nu \rho\end{array}$ \\
\hline & $\begin{array}{l}\text { vowels followed by } \\
\gamma \mu \gamma \nu \delta \mu \delta v\end{array}$ & long & \\
\hline & $\begin{array}{l}\text { adjacent vowels } \\
\text { (e. g., } \varepsilon \omega)\end{array}$ & $\begin{array}{l}\text { (may collapse } \\
\text { into one) long }\end{array}$ & $\begin{array}{l}\text { This is called synizesis. Its imple- } \\
\text { mentation in Dactylo is limited to } \\
\text { a set of enumerated words such as } \\
\Pi \eta \lambda \eta \ddot{i \alpha ́} \delta \varepsilon \omega \text { in Iliad, I, } 1 \text {. }\end{array}$ \\
\hline & $\begin{array}{l}\text { short syllables at the } \\
\text { beginning of } 5^{\text {th }} \text { half } \\
\text { foot }\end{array}$ & & $\begin{array}{l}\text { This is intended to address a re- } \\
\text { quirement for support of brevis in } \\
\text { arsi. Short syllables at the begin- } \\
\text { ning of } 5^{\text {th }} \text { half foot will be ac- } \\
\text { cepted as long if they are the last } \\
\text { syllable in the word (i. e., poten- } \\
\text { tially preceding a caesura). }\end{array}$ \\
\hline
\end{tabular}

Table 1: Hexameter scanning rules in Dactylo

Another software tool, capable of scanning the hexameter, is the expert system of Daniele Fusi $(2001 ; 2002 ; 2004 ; 2008 ; 2015)$, which can scan other metrical patterns (e. g., elegiacs, trimeters, etc.), as well, in Ancient Greek, Latin and Italian poetry. This comprehensive system covers a wider spectrum of linguistic phenomena, by using different modules for prosody, syntax and metrics. Moreover, the output of it generates report files concerning many linguistic phenomena. 


\subsection{Research objectives and data}

The purpose of this research is to introduce the concept of metric profiling and to show some of the data collected during this work. All data collected (more than those listed in the report) can be made available on request for further investigation. On this ground, the present study has two goals:

- Automatically (through computer software) determine the actual metric patterns of the huge number of verses in classical epics (in total about 67,000) as a sequence of long and short syllables.

- Collect and present statistical information related to the poets' preferences of, or aversions against, the possible patterns that may exist in a hexameter verse, and based on these statistics, compare authors and their works across the timeline.

The types of data analyzed included the following works:

- Iliad (Homer);

- Odyssey (Homer);

- Theogony (Hesiod);

- Works and Days (Hesiod);

- Phaenomena (Aratus Solensis);

- Argonautica (Apollonius Rhodius);

- Fall of Troy/Posthomerica (Quintus Smyrnaeus);

- Dionysiaca (Nonnus of Panopolis).

This selection of works is intended to allow for a comparison of feet distribution, in different periods of Ancient Greek epic poetry; in particular:

- Homer, Hesiod $\left(8^{\text {th }} / 7^{\text {th }}\right.$ century BCE);

- Aratus Solensis, Apollonius Rhodius ( $3^{\text {rd }}$ century BCE);

- Quintus Smyrnaeus, Nonnus Of Panopolis $\left(4^{\text {th }} / 5^{\text {th }}\right.$ century CE).

Based on the distribution patterns of the verses, profiles can be calculated of the relative frequencies of these patterns within the works. These profiles are called metric profiles within this document. Once these profiles have been established, comparison can be performed of profiles of different authors across the centuries, such as to observe and describe the evolution of these preferences from the early days of ancient Greek epic poetry, to their latest days. The source code (these works) was copied into a text editor and saved in UTF-8 encoding. UTF-8 stands for Universal Character Set Transformation-8 bit, and is a character encoding that allows representing all possible characters defined by Unicode, the computing industry standard for encoding most of the world's writing systems. This particular encoding allows the processing of polytonal Greek fonts.

The number of verses available for analysis, along with a few comments, can be seen in Table 2. Hesiod's works are analysed as a compilation of Theogony (as Book 1) and Works and Days (as Book 2). The purpose here is to broaden the statistical base for the calculation of metric profiles, (see below subsection: 3.1 Metric profiling) as both works alone are much shorter than any of Iliad, Odyssey, Argonautica, and Dionysiaca. Even counted together, these Hesiod works 
have less than 2,000 verses, so any slight fluctuations or irregularities in the analysis of these works have a larger impact onto the overall results.

\begin{tabular}{|c|c|c|}
\hline Epic & $\begin{array}{c}\text { Number of } \\
\text { verses }\end{array}$ & Comments \\
\hline Iliad & 15,683 & \\
\hline Odyssey & 12,105 & \\
\hline Hesiod's works & 1,853 & $\begin{array}{l}\text { Assembly of Theogony and of Works and Days. } \\
\text { Theogony: " } \Sigma \eta \mu \varepsilon i \omega \sigma \eta " \text { after verse } 929 \text { is not included in this } \\
\text { analysis }\end{array}$ \\
\hline Phaenomena & 1,155 & \\
\hline Argonautica & 5,834 & \\
\hline Posthomerica & 8,804 & \\
\hline Dionysiaca & 21,260 & $\begin{array}{l}\text { Some apparent errors in line numbering evident in the data } \\
\text { source (Perseus Project) have been corrected. }\end{array}$ \\
\hline
\end{tabular}

Table 2: Works under analysis

\section{$3 \quad$ Methodology}

As outlined above, this study is based on computerized scanning of hexameter. The software tools, developed for this purpose by the name Dactylo, reads verses line by line, scans for the hexameter pattern (i. e., the sequence of long and short syllables compliant with hexameter rules) and outputs the verses along with their determined pattern to simple text files, for further investigation and processing. Before Dactylo scans a text, it is transformed from original Greek characters into an internal format, using Latin characters. This is done primarily for practical reasons, having to do with computing environments of limited or no support for Greek characters. It also facilitates the handling of some grammatical phenomena, like diaeresis and circumflex. As an illustration of this internal transformation, the first few lines of Iliad in original Greek and in transformed versions are given in Table 3.

Each verse is then output along with an identifier and with the determined pattern of long and short syllables, as for example the result for the first verse (0001) of Book 1 (Rhapsody I) of Iliad (IL01):

\section{IL01 $0001 *$ OK*mHnin aeide Tea phlhjade0 axilHos*LSSLSSLLLSSLSSLS.}

Statistical information, created in the scanning process, comprises:

- Number of verses in the epic (or Book).

- Number of verses for which the metric pattern could not be identified (reported as irregular pattern).

- Number of verses in each of the 32 possible metric patterns (further organized in metric profiles, see below).

- Number of verses for which Dactylo finds more than one matching pattern (see section: Results and Discussion). 


\begin{tabular}{|c|c|}
\hline Original Greek Text & Latin Transformation \\
\hline 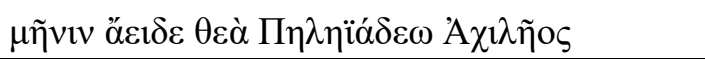 & mHnin aeide Tea phlhjade 0 axilHos \\
\hline 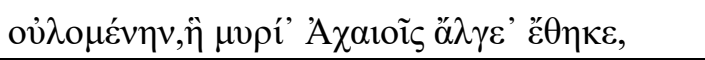 & oylomenhn $\mathrm{h}$ myri axaioIs alge eThke \\
\hline 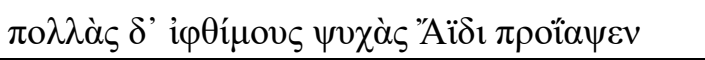 & pollas d ifTimoys Syxas ajdi projaSen \\
\hline 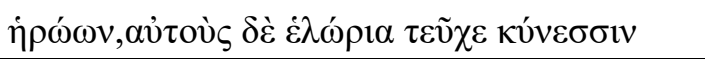 & hr00n aytoys de el0ria teYxe kynessin \\
\hline oỉ & oi0noIsi te pAsi dios d eteleieto boylh \\
\hline 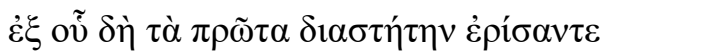 & eX oY dh ta prOta diasththn erisante \\
\hline A & atrejdhs te anaX andrOn kai dIos axilleys \\
\hline
\end{tabular}

Table 3: Internal transformation from Greek to Latin characters

The core consideration is the following: hexameters are built from sequences of 6 feet that each are either 3 syllables building a dactyl (scanning long-short-short), or 2 syllables building a spondee (scanning long-long). The exception is the last foot that has only 2 (never 3 ) syllables, and scans either long-long or long-short. However, the rhythmic impression of the last foot will always be that of a spondee (long-long) because of the following break at the end of the verse.

\subsection{Metric profiling}

Looking onto foot one to foot five of a verse, and not distinguishing between long-long and long-short in the last foot, one can distinguish 32 patterns of hexameter (i. e., different combinations of dactyls and spondees). For each of these patterns, one can measure the relative frequency by which that pattern appears in the verses of the text in question. The full metric profile then captures the information of how frequently each pattern occurs in the work, in terms of relative frequencies (percentage of occurrences). Because these frequencies are given in relative (not absolute) values, the concept allows for comparison of profiles of works that differ in length (number of verses). The metric profile is hence a table of 32 numbers that each denotes the percentage of verses in a work that are built to the specific pattern at this table position. Table 4 enumerates and defines the 32 hexameter patterns within the metric profile.

As shown in Table 4 (see below):

- "Pat. id" ("Pattern id") is a sequential numbering of hexameter patterns, from 01 (all dactyls) to 32 (all spondees). The irregular pattern is a hypothetic pattern assigned to verses not successfully scanned as hexameters (for details, see below subsection: 4.1 Irregular patterns).

- "Pattern descriptor" is a combination of D (for a dactyl in this position) and S (for a spondee in this position), terminated by an $[\mathrm{x}]$ in the last position (where we don't distinguish between dactyl and spondee).

- "Scanned as" gives the full scan of the pattern as a sequence of LSS (long-short-short) and LL (long-long), with LS possible for the scan of the last foot.

In addition to the full metric profile described above, an additional compact metric profile is also calculated. 


\begin{tabular}{|c|c|c|c|c|c|}
\hline $\begin{array}{c}\text { Pat. } \\
\text { id }\end{array}$ & $\begin{array}{c}\text { Pattern } \\
\text { short } \\
\text { descriptor }\end{array}$ & Scanned as & $\begin{array}{l}\text { Pat. } \\
\text { id }\end{array}$ & $\begin{array}{l}\text { Pattern short } \\
\text { descriptor }\end{array}$ & Scanned as \\
\hline 01 & DDDDDx & LSSLSSLSSLSSLSSLx & 18 & SDDDSx & LLLSSLSSLSSLLLx \\
\hline 02 & DDDDSx & LSSLSSLSSLSSLLLx & 19 & SDDSDx & LLLSSLSSLLLSSx \\
\hline 03 & DDDSDx & LSSLSSLSSLLLSSx & 20 & SDDSSx & LLLSSLSSLLLLx \\
\hline 04 & DDDSSx & LSSLSSLSSLLLLx & 21 & SDSDDx & LLLSSLLLSSLSSLx \\
\hline 05 & DDSDDx & LSSLSSLLLSSLSSLx & 22 & SDSDSx & LLLSSLLLSSLLLx \\
\hline 06 & DDSDSx & LSSLSSLLLSSLLLx & 23 & SDSSDx & LLLSSLLLLLSSLx \\
\hline 07 & DDSSDx & LSSLSSLLLLLSSLx & 24 & SDSSSx & LLLSSLLLLLLLx \\
\hline 08 & DDSSSx & LSSLSSLLLLLLLx & 25 & SSDDDx & LLLLLSSLSSLSSLx \\
\hline 09 & DSDDDx & LSSLLLSSLSSLSSLx & 26 & SSDDSx & LLLLLSSLSSLLLx \\
\hline 10 & DSDDSx & LSSLLLSSLSSLLLx & 27 & SSDSDx & LLLLLSSLLLSSLx \\
\hline 11 & DSDSDx & LSSLLLSSLLLSSLx & 28 & SSDSSx & LLLLLSSLLLLLx \\
\hline 12 & DSDSSx & LSSLLLSSLLLLLx & 29 & SSSDDx & LLLLLLLSSLSSLx \\
\hline 13 & DSSDDx & LSSLLLLLSSLSSLx & 30 & SSSDSx & LLLLLLLSSLLLx \\
\hline 14 & DSSDSx & LSSLLLLLSSLLLx & 31 & SSSSDx & LLLLLLLLLSSLx \\
\hline 15 & DSSSDx & LSSLLLLLLLSSLx & 32 & SSSSSx & LLLLLLLLLLLx \\
\hline 16 & DSSSSx & LSSLLLLLLLLLx & \multirow{2}{*}{ IR } & \multirow{2}{*}{ IRREGULAR } & \multirow{2}{*}{ Irregular scan } \\
\hline 17 & SDDDDx & LLLSSLSSLSSLSSLx & & & \\
\hline
\end{tabular}

Table 4: Full metric patterns of hexameter

The compact metric profile is a table of six entries, each one giving the percentage of verses by which the $1^{\text {st }}, 2^{\text {nd }}, 3^{\text {rd }}, 4^{\text {th }}, 5^{\text {th }}$, or $6^{\text {th }}$ foot, respectively, in the verses scan long-long (i. e., as a spondee) as opposed to scanning long-short-short (i. e., as a dactyl). The compact metric profile is hence built as defined in Table 5 .

\begin{tabular}{|l|l|l|}
\hline \multicolumn{1}{|c|}{ Foot id } & \multicolumn{1}{|c|}{ Short descriptor } & \multicolumn{1}{c|}{ Description } \\
\hline 01 & $\mathrm{~S}^{* * * * *}$ & spondee in $1^{\text {st }}$ foot \\
\hline 02 & $* \mathrm{~S}^{* * * *}$ & spondee in $2^{\text {nd }}$ foot \\
\hline 03 & $* * \mathrm{~S}^{* * *}$ & spondee in $3^{\text {rd }}$ foot \\
\hline 04 & $* * * \mathrm{~S}^{* *}$ & spondee in $4^{\text {th }}$ foot \\
\hline 05 & $* * * * \mathrm{~S}^{*}$ & spondee in $5^{\text {th }}$ foot \\
\hline 06 & $* * * * * \mathrm{~S}$ & scan of long-long in $6^{\text {th }}$ foot \\
\hline
\end{tabular}

Table 5: Compact metric patterns 
In Table 5:

- "Foot id" identifies the foot (from 1 to 6).

- "Short descriptor" and "Description" correspond to Foot id and show that the pattern has a spondee in the specific foot identified by "Foot id".

Note that in the compact profile, the table maintains the distinction between long-long and longshort in the last $\left(6^{\text {th }}\right)$ foot of the verse.

\subsection{Profile comparison}

Once metric profiles have been obtained for the works in scope, it is possible to compare profiles with one another. This can be done on a work-to-work level (e. g., comparison of metric profile of Iliad with metric profile of Odyssey) and on a work-to-part level (e. g., comparison of metric profile of individual Iliad Books with metric profile of the entire Iliad epic). The idea is the following: if metric profiles of two works or parts are found to be very similar, then one might consider assuming that they may have been written by the same author. For this idea, the metric profile is sometimes also thought to be a metric fingerprint (though one will not necessarily give it the same power of proof as, e. g., the fingerprint in criminology). Reversely, if metric profiles of two works are considerably different, one might think of assuming different authors for these works or parts. Whether any such conclusions can indeed be drawn, is outside the scope of judgement of the authors herein.

Within this context, Dactylo introduces a numeric value called the metric distance between two metric profiles. Metric distances have been introduced to help quickly identify works, whose metric profiles are specifically different from the profile of a reference work (larger values of metric distances) or whose metric profiles are specifically similar (smaller values).

\subsection{Metric distance}

The metric distance is a measurement value that reflects the degree of similarity, or of dissimilarity, between two compared metric profiles, or in other words, between the rhythmic preferences exhibited in these works. The metric distance of a work $\mathrm{X}$ under investigation, to a work B taken as base, is a number calculated using the formula:

$$
\sqrt{\sum_{i=1}^{33}\left(x_{i}-b_{i}\right)^{2}}
$$

where $\left[\mathrm{x}_{\mathrm{i}}\right]$ and $\left[\mathrm{b}_{\mathrm{i}}\right]$ are the relative frequencies of the $\mathrm{i}$-th pattern within the works (with the irregular pattern picked at $i=33$ ). The formula hence calculates the differences of the percentages for all patterns, then squares that number (so as to make the value positive and to make large differences even larger and small differences even smaller), adds up these numbers to a total value and finally scales the result back by taking the square root. The result is a somewhat synthetic number whose actual numeric value is of limited natural meaning, but which can be useful for ordering (ranking) texts by their metric distances from reference texts.

\section{$4 \quad$ Results and discussion}

Dactylo provides collected statistical information across all works in the study, in terms of full metric profiles, compact metric profiles and mutual metric distances, solely regarding the 
distribution of feet. In the current version, it finds the hexameter pattern for roughly $95 \%$ (Homer, Hesiod) to 98\% (Apollonius) and 99\% (Nonnus) of verses. Before some of this information is presented though, starting with the Dactylo's listings, the nature of failure rate or other irregularities should be firstly commented, considering irregular and multiple hexameter patterns.

\subsection{Irregular patterns}

Not being able to determine the hexameter scanning of a verse can have the following reasons:

- Incomplete scanning rules built into Dactylo, e. g., with respect to contraction.

- Scanning rules can also be used somewhat inconsistently by ancient authors. For example, in Iliad, the consonant sequence of $\{\mathrm{sk}\}$ at (or after) the end of a syllable will normally cause that syllable to scan long (positional lengthening due to two or more consonants following a vowel). However, if these consonants build the beginning of the name of the river "Skamandros" then the preceding syllable, if built on a short or anceps vowel, will scan short.

- For the epics of Homer (Iliad and Odyssey), research has pointed out for a long time that a number of verses reflect traces of Mycenaean Greek, i. e., a level of the Greek language that is much older than Classical Ancient Greek, and also much older than the Greek language (in any dialect) that was contemporary with Homer's days (approx. $700 \mathrm{BCE}$ ). If a verse does not validly scan as hexameter, then it might do so if Mycenaean forms of words, or elements of Mycenaean grammar, were restored to that verse. This is described in some detail in Joachim Latacz: "Troia und Homer" (Latacz 2010). For example, in Mycenaean Greek, some words or syllables used to start with a phoneme that sounded like /w/ which later disappeared in Greek, as a written sign. The Greek alphabet had a letter called DIGAMMA (written similar to the Latin letter "F") to denote this phoneme. Some of Homer's verses that do not appear to comply with hexameter scanning rules, would turn into valid hexameters if DIGAMMA were re-introduced to words from which it had disappeared (Note: A separate thread of the Dactylo project - not yet documented here - deals more closely with identifying irregular verses in Homer's epics, and with applying "what-if" analysis that examines the results of re-introduction of Mycenaean levels of Greek language for certain words, for example, to see how the outcome is affected if "Ilios" is replaced by "Filios" - with leading DIGAMMA - in all verses where the word is found).

- Editions do also deviate in writing from one another, e. g., the word " $\varepsilon \varsigma$ " (preposition with accusative meaning "into", found in the Iliad edition used in this project) scans short, while the same word has been seen in its alternate form " $\mathrm{elc}$ " in the same place in another edition, scanning long (for centuries, the works had being copied by hand, even when prosodic features had disappeared and words had changed).

- Occasionally, verses have been encountered that are somewhat mis-edited on the web sites from which they have been downloaded for Dactylo, thus introducing errors in the hexameter scan.

- Where none of the above appears to apply, more sophisticated scanning rules are required that are not embedded in Dactylo. 
The rate of verses, not validly scanned as hexameters by Dactylo, is in the $5 \%$ magnitude for Homer's and Hesiod's works, dropping to $2 \%$ for Argonautica and to $1 \%$ for Dionysiaca. The statistical base for calculation of metric profiles still appears broad enough, being in the $95 \%$ to $99 \%$ range of the verses for all works in the analysis. Further improving the Dactylo's hit rate will be subject to future work in the project, if determined to be valuable.

\subsection{Multiple patterns}

Another slight irregularity is the (rare) occurrence of verses for which Dactylo identifies more than one applicable hexameter pattern. According to the automated scanning, these verses can be pronounced as a hexameter in more than one way. For a number of these verses, it is probable that a trained human speaker might acknowledge only one way of scanning. An example of such a verse is the $3^{\text {rd }}$ one in Rhapsody I of Iliad (IL01 0003):

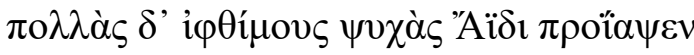

which is scanned in Dactylo's internal transcript as:

- IL01 0003*MULT*pollas d iPTimoys SyKas ajdi projaSen*LLLLLSSLLLSSLS

- IL01 0003*MULT*pollas d iPTimoys SyKas ajdi projaSen*LLLLLLLSSLSSLS

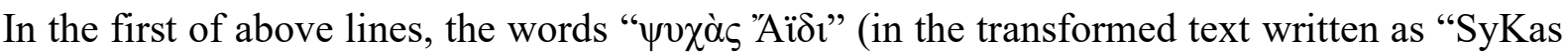
ajdi") are scanned SSLLL, while in the second one they are scanned LLSSL. Both will deliver a valid, yet different, hexameter pattern to the full verse.

These multiple possible patterns is a symptom of shortcomings in Dactylo's scanning capabilities that can be judged by philologists, more competent in hexameter reading than the authors of this document. In the case of a verse with multiple matches, then for calculation of pattern statistics, Dactylo will pick the pattern that is generally more frequent in all of the works in the analysis, though this may not be the best choice in individual cases. For example, the above verse IL01 0003 will be assigned a match with Pattern id 27 (Table 4) and will count the scan as LLLLSSLLLSSLS, because across all works, 27 is encountered more frequently than 29 (the alternate and also preferable scan for this verse). A separate additional output file is created for these verses that lists all possible scans. The number of verses, for which Dactylo finds multiple applicable hexameter patterns, is small. In all of Iliad, 125 verses fall into that group, out of a statistical base of nearly 16,000 .

\subsection{Dactylo listings}

The complete scanning results for the epics can be seen in a number of flat text files. Listings are available for the entire epic, as well as for the individual Books (or songs) that constitute the epic (except for Theogony, as it is a rather short work). The naming convention for the prefix portion of the names of the listings is described in Table 6.

The full file name is constructed by appending a suffix as per Table 7. For example, to inspect the scanning of all verses in Iliad, the listing to be consulted is IL_ALL_OUT_1RESULT.TXT. To review the metric profile of Book 10 (Rhapsody X) of Iliad, the listing to consult is IL10_OUT_4PROFILE.TXT. 


\begin{tabular}{|c|c|c|}
\hline Epic & Prefix & Content \\
\hline \multirow[t]{2}{*}{ Iliad } & IL_ALL_OUT_ & full Iliad (24 Books) \\
\hline & ILnn_TR_OUT_ & Book nn (from 01 to 24 ) of Iliad \\
\hline \multirow[t]{2}{*}{ Odyssey } & OD_ALL_OUT & full Odyssey (24 Books) \\
\hline & ODnn_TR_OUT_ & Book nn (from 01 to 24) of Odyssey \\
\hline \multirow[t]{2}{*}{ (Hesiod) } & HE_THEO_OUT_ & Theogony \\
\hline & HE_WORKS_OUT_ & Works and Days \\
\hline \multirow[t]{2}{*}{ Argonautica } & ARGO_ALL_OUT_ & full Argonautica (4 Books) \\
\hline & ARGO_nn_OUT_ & Book nn (from 01 to 04 ) of Argonautica \\
\hline \multirow[t]{2}{*}{ Dionysiaca } & DION_ALL_OUT_ & full Dionysiaca (48 Books) \\
\hline & DION nn OUT & Book nn (from 01 to 48 ) of Dionysiaca \\
\hline
\end{tabular}

Table 6: Dactylo naming conventions for works

\begin{tabular}{|c|c|c|}
\hline Suffix & Content & Comment \\
\hline 1RESULT.TXT & result listing & $\begin{array}{l}\text { all verses along with either their scanning, or } \\
\text { an indicator if not scanned correctly }\end{array}$ \\
\hline 2IRR.TXT & irregular verses & $\begin{array}{l}\text { verses for which the valid scheme could not be } \\
\text { determined }\end{array}$ \\
\hline 3DETAIL.TXT & $\begin{array}{l}\text { internal diagnostics informa- } \\
\text { tion }\end{array}$ & not currently provided for download \\
\hline 4PROFILE.TXT & hexameter profile & $\begin{array}{l}\text { profile information in form of the metric pro- } \\
\text { file as explained previously }\end{array}$ \\
\hline 5STAT.TXT & statistics & statistical information \\
\hline 6MULT.TXT & $\begin{array}{l}\text { verses with multiple scan- } \\
\text { nings }\end{array}$ & $\begin{array}{l}\text { verses for which Dactylo finds more than one } \\
\text { possible hexameter scanning }\end{array}$ \\
\hline 7BREV.TXT & verses with brevis in arsi rule & $\begin{array}{l}\text { verses that show a formally short syllable at } \\
\text { the position of the } 5^{\text {th }} \text { half foot; the syllable is } \\
\text { however scanned as long }\end{array}$ \\
\hline
\end{tabular}

Table 7: Text files produced by Dactylo

\subsection{Full metric profiles per epic}

In essence, this is a list of the relative frequencies of all 32 hexameter patterns (plus the irregular one) of the verses in these works under investigation (Table 8). The quoted numbers give the percentages of verses in the respective works that match with the pattern designated in the first and second column. In top-down reading, each of the columns shows the full metric profile of the corresponding work. In left-right reading, a comparison for a specific hexameter pattern is enabled between these works. 


\begin{tabular}{|c|c|c|c|c|c|c|c|c|}
\hline ID & PATTERN & ILIAD & ODYSSEY & HESIOD & $\begin{array}{c}\text { PHAENO- } \\
\text { MENA }\end{array}$ & \begin{tabular}{c||} 
ARGO- \\
NAUTICA
\end{tabular} & $\begin{array}{c}\text { POST- } \\
\text { HOMER }\end{array}$ & $\begin{array}{l}\text { DIONY- } \\
\text { SIACA }\end{array}$ \\
\hline 01 & DDDDDX & 19.2 & 18.3 & 16.9 & 17.1 & 21.6 & 34.5 & 38.4 \\
\hline 02 & DDDDSX & 1.1 & 0.88 & 1.1 & 3.7 & 2.5 & 3.2 & 0.047 \\
\hline 03 & DDDSDX & 8.6 & 8.3 & 6.6 & 5 & 6.4 & 6.8 & 14.5 \\
\hline 04 & DDDSSX & 0.35 & 0.38 & 0.38 & 0.43 & 0.017 & 0.056 & 0.018 \\
\hline 05 & DDSDDX & 4.1 & 4 & 4 & 6.1 & 5.7 & 2.8 & 2.1 \\
\hline 06 & DDSDSX & 0.22 & 0.18 & 0.54 & 0.87 & 0.67 & 0.11 & 0.009 \\
\hline 07 & DDSSDX & 1.3 & 1.4 & 1.5 & 0.78 & 0.26 & 0.16 & 0.028 \\
\hline 08 & DDSSSX & 0.051 & 0.041 & 0.11 & 0 & 0 & 0 & 0 \\
\hline 09 & DSDDDX & 13.9 & 14.6 & 14.7 & 12.4 & 19.4 & 17.5 & 20.8 \\
\hline 10 & DSDDSX & 0.7 & 0.78 & 0.86 & 3 & 2.2 & 1.5 & 0.042 \\
\hline 11 & DSDSDX & 6.2 & 6.6 & 6 & 4.5 & 5.5 & 3.2 & 8.6 \\
\hline 12 & DSDSSX & 0.3 & 0.24 & 0.27 & 0.17 & 0.034 & 0.068 & 0.009 \\
\hline 13 & DSSDDX & 3 & 3.6 & 2.9 & 5.1 & 3.8 & 1.1 & 0.45 \\
\hline 14 & DSSDSX & 0.18 & 0.25 & 0.32 & 0.61 & 0.36 & 0.056 & 0 \\
\hline 15 & DSSSDX & 0.66 & 0.78 & 0.97 & 0.26 & 0.085 & 0.11 & 0.014 \\
\hline 16 & DSSSSX & 0.076 & 0.016 & 0.053 & 0 & 0 & 0 & 0 \\
\hline 17 & SDDDDX & 13.2 & 11.4 & 11.2 & 11.9 & 10.8 & 15.1 & 9.5 \\
\hline 18 & SDDDSX & 0.92 & 0.84 & 0.76 & 2.9 & 1.3 & 1.2 & 0.004 \\
\hline 19 & SDDSDX & 5.7 & 6.1 & 5.3 & 3.7 & 2.9 & 2.7 & 3.9 \\
\hline 20 & SDDSSX & 0.2 & 0.26 & 0.43 & 0.17 & 0.017 & 0.011 & 0.009 \\
\hline 21 & SDSDDX & 2.8 & 2.9 & 3 & 3.5 & 2.8 & 0.77 & 0.41 \\
\hline 22 & SDSDSX & 0.13 & 0.099 & 0 & 0.35 & 0.34 & 0.045 & 0.004 \\
\hline 23 & SDSSDX & 0.82 & 0.69 & 0.81 & 0.69 & 0.051 & 0.045 & 0.014 \\
\hline 24 & SDSSSX & 0.019 & 0 & 0 & 0 & 0 & 0 & 0 \\
\hline 25 & SSDDDX & 7.2 & 7.8 & 9.2 & 7.8 & 7.6 & 5.1 & 0.047 \\
\hline 26 & SSDDSX & 0.48 & 0.47 & 0.38 & 1.6 & 1.1 & 0.49 & 0 \\
\hline 27 & SSDSDX & 3.4 & 3.8 & 3.2 & 3 & 1.8 & 0.9 & 0.009 \\
\hline 28 & SSDSSX & 0.11 & 0.14 & 0.27 & 0 & 0 & 0.011 & 0 \\
\hline 29 & SSSDDX & 1.1 & 1.4 & 1.8 & 1.3 & 0.72 & 0.24 & 0 \\
\hline
\end{tabular}




\begin{tabular}{|c|c|c|c|c|c|c|c|c|}
\hline ID & PATTERN & ILIAD & ODYSSEY| & HESIOD & \begin{tabular}{|c} 
PHAENO- \\
MENA
\end{tabular} & \begin{tabular}{|c||} 
ARGO- \\
NAUTICA
\end{tabular} & $\begin{array}{c}\text { POST- } \\
\text { HOMER }\end{array}$ & $\begin{array}{l}\text { DIONY- } \\
\text { SIACA }\end{array}$ \\
\hline 30 & SSSDSX & 0.057 & 0.049 & 0.16 & 0.26 & 0.068 & 0 & 0 \\
\hline 31 & SSSSDX & 0.28 & 0.31 & 0.49 & 0.17 & 0.051 & 0.011 & 0 \\
\hline 32 & SSSSSX & 0.012 & 0.033 & 0 & 0 & 0 & 0 & 0 \\
\hline IR & IRREGULAR & 3.7 & 3.5 & 5.5 & 2.5 & 2.1 & 2.2 & 1.1 \\
\hline
\end{tabular}

Table 8: Full metric profiles per epic

Some noticeable observations are the following:

- As it can be seen from Table 8, pattern DDDDDX (called "holodactylic", namely consisting of all dactyls) appears to be the most frequent pattern, because of its much higher relative frequency in Dionysiaca (around 38\%) than in any of the other works (around 17\% to $21 \%$ ).

- Pattern DSDDDX (just one spondee in the $2^{\text {nd }}$ foot) holds the second rank in all works, again with highest share in Dionysiaca (around 20\%), slightly ahead of Argonautica.

- Comparing Iliad and Odyssey columns, one finds very similar values for practically all hexameter patterns. By and large, the metric profiles of Iliad and Odyssey are the same.

- The Hesiod column is slightly, yet noticeably different from the profiles related to Homer, with Phaenomena and Argonautica again a bit more different, while Posthomerica and Dionysiaca columns show considerably different values.

- Noticeably also, pattern 25 (SSDDDX) that is very frequently used in the other works, is hardly encountered at all (only $0.032 \%$ ) in Dionysiaca. Similarly, the frequencies for patterns 26 to 32 indicate a strong aversion, in Dionysiaca, against beginning a verse with two spondees. Only 9 (out of more than 21,000 verses) show two consecutive spondees at the beginning.

- Pattern SSSSSX (all spondee, also known as holospondaeus) is unfrequent, yet it does occur four times in Odyssey (thereof twice in Book 22), and twice in Iliad. No occurrence has been found in the other works.

Generally, Dionysiaca uses very few patterns to cover the vast majority of the verses. The top 5 patterns account for $92 \%$ of all Dionysiaca verses, followed by $79 \%$ in Posthomerica, while for all of the other works, the top 5 patterns cover around $60 \%$ of all verses ((a) in Table 9). Reversely, while Dionysiaca don't have any verses in its 10 least used patterns, the other works have several verses also in these patterns, with the older works (Homer and Hesiod) more than Phaenomena and Argonautica ((b) in Table 9). 


\begin{tabular}{|l|r|l|r|}
\hline \multicolumn{1}{|c|}{ Epic } & (a): Top 5 in $\%$ & \multicolumn{1}{c|}{ Epic } & (b): Bottom 10 in \% \\
\hline Dionysiaca & 91.8 & Hesiod works & 1.56 \\
\hline Posthomerica & 79.0 & Odyssey & 1.05 \\
\hline Argonautica & 65.8 & Iliad & 1.05 \\
\hline Iliad & 62.1 & Phainomena & 1.03 \\
\hline Odyssey & 60.4 & Argonautica & 0.17 \\
\hline Hesiod works & 58.6 & Posthomerica & 0.12 \\
\hline Phaenomena & 55.3 & Dionysiaca & 0.00 \\
\hline
\end{tabular}

Table 9: Top and bottom patterns per epic

\subsection{Compact metric profiles per epic}

Table 10 shows the compact metric profiles of the works under investigation. It lists the relative frequencies, in percent, of occurrences of a spondee in each of the six feet of the hexameter scan of the verse. For this statistics, verses with irregular pattern are ignored; only validly scanned verses are taken into account. In top-down reading, each of the columns Iliad, Odyssey, Hesiod, Phaenomena, Argonautica, Posthomer(ica), and Dionysiaca show the compact metric profile of the work. In left-right reading, a comparison for a spondee in a specific position is enabled between these works.

Some noticeable observations:

- As expected, the foot that shows a spondee least frequently is foot 5 in all works. However, both Homer's and Hesiod's works show a spondee in foot 5 in approx. 5\% to $6 \%$ of their verses, Argonautica and Posthomerica increase this to $7 \%$ to $9 \%$, Phaenomena hold the top with nearly $15 \%$, while Dionysiaca exhibit this behaviour extremely rarely ( $0.1 \%$ of verses).

- In foot 6, Homer's epics, Hesiod's texts, Phaenomena, Argonautica and Posthomerica don't seem to bother a lot about the formal length of the last syllable; it will roughly show a 50/50 mix.

- Dionysiaca is very different in that the last syllable is formally long in nearly $87 \%$ of verses. In contrast, Dionysiaca show a spondee very rarely in foot 1 , foot 2 , and foot 3 , compared to the other works in analysis.

\begin{tabular}{|c|c|c|c|c|c|c|c|c|}
\hline ID & PATTERN & ILIAD & ODYSSEY & HESIOD & $\begin{array}{c}\text { PHAENO- } \\
\text { MENA }\end{array}$ & $\mid \begin{array}{c}\text { ARGO- } \\
\text { NAUTICA }\end{array}$ & $\begin{array}{c}\text { POST- } \\
\text { HOMER }\end{array}$ & $\begin{array}{l}\text { DIONY- } \\
\text { SIACA }\end{array}$ \\
\hline 01 & SXXXXX & 37.85 & 37.5 & 39.29 & 38.36 & 30.05 & 27.23 & 14.05 \\
\hline 02 & XSXXXX & 39.1 & 42.23 & 44.08 & 41.2 & 43.45 & 30.99 & 30.29 \\
\hline 03 & XXSXXX & 15.31 & 16.26 & 17.64 & 20.6 & 15.15 & 5.6 & 3.01 \\
\hline
\end{tabular}




\begin{tabular}{|c||c|r|r|r|r||r|r|r|}
\hline \multirow{2}{*}{ ID } & PATTERN & ILIAD & ODYSSEY & HESIOD & $\begin{array}{c}\text { PHAENO- } \\
\text { MENA }\end{array}$ & $\begin{array}{c}\text { ARGO- } \\
\text { NAUTICA }\end{array}$ & $\begin{array}{c}\text { POST- } \\
\text { HOMER }\end{array}$ & $\begin{array}{c}\text { DIONY- } \\
\text { SIACA }\end{array}$ \\
\hline \hline 04 & XXXSXX & 29.14 & 30.06 & 28.04 & 19.44 & 17.48 & 14.41 & 27.44 \\
\hline 05 & XXXXSX & 5.12 & 4.83 & 5.99 & 14.47 & 8.75 & 6.79 & 0.14 \\
\hline \hline 06 & XXXXXS & 49.75 & 47.47 & 49.28 & 53.9 & 41.37 & 43.17 & 86.97 \\
\hline
\end{tabular}

Table 10: Compact metric profiles per epic

\subsection{Mutual metric distances}

Table 11 gives the mutual metric distances (distances of full metric profiles) for the works in analysis, where values given are metric distances of the full metric profile of an epic, against the metric profile of a base work (given in the leftmost column).

\begin{tabular}{|c|c|c|c|c|c|c|c|}
\hline BASE & Iliad & Odyssey & Hesiod & Phaenomena & Argonautica & Posthomer & Dionysiaca \\
\hline ILIAD & 0 & 2.5 & 4.7 & 7.6 & 8.4 & 17.4 & 23.8 \\
\hline ODYSSEY & 2.5 & 0 & 3.6 & 7.5 & 8.2 & 18.7 & 24.5 \\
\hline HESIOD & 4.7 & 3.6 & 0 & 7.3 & 8.9 & 20 & 26.7 \\
\hline PHAENOMENA & 7.6 & 7.5 & 7.3 & 0 & 9.2 & 20 & 28.2 \\
\hline ARGONAUTICA & 8.4 & 8.2 & 8.9 & 9.2 & 0 & 14.9 & 21.6 \\
\hline POSTHOMER & 17.4 & 18.7 & 20 & 20 & 14.9 & 0 & 13.8 \\
\hline DIONYSIACA & 23.8 & 24.5 & 26.7 & 28.2 & 21.6 & 13.8 & 0 \\
\hline
\end{tabular}

Table 11: Mutal metric distances of epics

The numeric value of the metric distance is quite synthetic and does not carry much natural meaning, other than allowing to order works by their metric distances. Obviously, values around 2 are small distances, 4 and 8 appear still a "near" yet a bit larger distance, while works with considerably different metric profiles show distances beyond 20 (as a reminder here: the purpose of this numeric value is to compare and sort distances of different works against a base work).

Some noticeable observations:

- Table 11 appears to suggest that there is a group of works with the smallest mutual metric distances of less than 5, consisting of Iliad, Odyssey, and Hesiod's works. Iliad and Odyssey are the works that are closest to each other, in terms of metric profiles, with Hesiod very slightly different. Taking Odyssey as a base, Hesiod is only very slightly more distant than Iliad. However, that statistical base for Hesiod is small (less than 2,000 verses) so the numbers in the profiles related to Hesiod are less reliable than those for the other authors. 
- Extending this group by Phaenomena and Argonautica gives a group of works with all mutual metric distances less than 10, whereby Phaenomena and Argonautica are no closer than 7 to any other work in the group.

- The rest of the works (Posthomerica and Dionysiaca) show a mutual metric distance of approx. 14, and are no closer than 15 (and up to 28) to any other work in the study. Dionysiaca is the work with biggest metric distances to other works in this study.

Based on metric distances, one would sort of group Iliad, Odyssey, and Hesiod's works in one group, then see Phaenomena and Argonautica in a second group, and finally Posthomerica and Dionysiaca in a third group. These groups would reflect very well the three periods of creation of these works.

\subsection{Metric profiles of Iliad and Odyssey}

It should be interesting to review the metric profiles of the 24 individual Iliad and 24 individual Odyssey Books, and compare them to the overall profile of the respective epic, taken across all 24 Books. Thus, one can identify Books that are considerably distant from the average and then examine whether this information correlates with current views on a single poet's ("Homer") authorship of these Books. To make identification easier of Books, whose metric profiles are particularly similar or dissimilar from the profile of the entire epic's average, Table 12 is presented below, including the metric distances of Books from the entire respective epic.

The Books of Iliad ((a) in Table 12) near the left top of its respective columns are most distant from the Iliad average ([IL_ALL $=0]$ ), while the Books near the right bottom are most similar to the average. Similarly for Odyssey ((b) in Table 12), the metric distances of Books are compared to the average $\left(\left[\mathrm{OD} \_\mathrm{ALL}=0\right]\right)$. Readers are kindly asked to remember that the numeric value of the metric distance is of no particular meaning in reality; it is just used for comparison (ranking) purposes.

Some noticeable observations:

- Of all Iliad's Books, Book 2 is the one whose profile differs most from the average Iliad's profile. For example, the relative frequency of the most frequent pattern (DDDDDX, meaning foot 1 through foot 5 are all dactyls) is only around $13.7 \%$, as opposed to $18.9 \%$ of the entire Iliad's epic. The frequency for many of the other patterns is also noticeably different from the average profile. This may have to do with the ships' catalogue within Book 2, which includes many names of individuals and places that, to some degree, pre-determine the metric patterns of the verses where they appear.

- The profiles of Books 21, 19, 12, and 9 follow Book 2, in descending order, regarding their metric distance from the Iliad's average.

- In contrast, Book 10 shows a metric profile very similar to the average Iliad profile. This is noticeable as Book 10 is generally considered a later addition to the epic, not written by Homer (e. g., see the comment of Iliad's translation for Book 10 from Schadewaldt 1975: 158f.). So a bigger metric distance of the metric profile of Book 10 from Iliad's average would have been expected, while in fact it cannot be observed in the table of metric distances. If someone was to take metric profiles as being able to indicate identity or diversity 
of authors (i. e., as metric fingerprints), the conclusion would be that Book 10 appears to have been written by the same author as most of the rest of Iliad.

- Odyssey Book 9 appears to be standing out a bit, in terms of differing from the average Odyssey's profile. With approx. 14\%, it shows a remarkably low rate for pattern 01 (all dactyls). Also, Odyssey Book 9 shows an approx. 7.6\% rate for the irregular pattern (i. e., verses whose hexameter scanning could not be determined by Dactylo), the by far highest rate among all the Books in this analysis.

\begin{tabular}{|r|r|r|r|r|r|r|r|}
\hline \multicolumn{5}{|c|}{ (a): ILIAD [IL_ALL $=0]$} & \multicolumn{4}{|c|}{ (b): ODYSSEY [OD_ALL = ] } \\
\hline Book & Distance & Book & Distance & Book & Distance & Book & Distance \\
\hline IL02 & 7.00 & IL14 & 4.06 & OD09 & 6.70 & OD11 & 4.42 \\
\hline IL21 & 6.03 & IL13 & 3.89 & OD01 & 5.87 & OD19 & 4.41 \\
\hline IL19 & 5.69 & IL20 & 3.89 & OD22 & 5.68 & OD03 & 4.20 \\
\hline IL12 & 5.46 & IL01 & 3.87 & OD18 & 5.65 & OD15 & 4.15 \\
\hline IL09 & 5.26 & IL24 & 3.83 & OD21 & 5.64 & OD07 & 4.07 \\
\hline IL03 & 5.17 & IL15 & 3.37 & OD14 & 5.59 & OD06 & 4.06 \\
\hline IL16 & 4.75 & IL10 & 3.21 & OD12 & 4.85 & OD17 & 3.80 \\
\hline IL08 & 4.69 & IL11 & 3.19 & OD23 & 4.82 & OD02 & 3.70 \\
\hline IL04 & 4.60 & IL06 & 2.76 & OD10 & 4.68 & OD08 & 3.67 \\
\hline IL07 & 4.39 & IL17 & 2.72 & OD05 & 4.56 & OD04 & 3.30 \\
\hline IL22 & 4.38 & IL23 & 2.02 & OD16 & 4.53 & OD24 & 3.08 \\
\hline IL18 & 4.20 & IL05 & 1.73 & OD13 & 4.43 & OD20 & 3.08 \\
\hline
\end{tabular}

Table 12: Metric distances of Homeric Books

\section{Conclusions}

Dactylo has demonstrated its ability to produce statistics of hexameter's feet distribution in a massive scale, easily and very accurately. One outcome of the work described in this document is the full listing of all of the epics in the study, presenting all verses along with their feet distribution that have been determined through scanning, or with an indication if that pattern could not be determined. For Homer's works, it appears also interesting to establish and then to compare the profiles of the individual Books of the epics with the average profile of the epic. The next question (outside the scope of this document) would be to examine what conclusions can be drawn from similarities or dissimilarities of these profiles. For each of these statistics, some initial noticeable observations have been also listed. The authors would be interested in learning, from readers that would be interested in acquiring the full listing of statistics, about other interesting findings in the collected numbers, as well as of possible conclusions and/or explanations. 


\section{References}

Annis, William S. (2006): Introduction to Greek Meter. aoidoi.org/articles/meter/intro.pdf [01.12.2016].

Apollonius Rhodius (s. a.): Argonautica. Edited by: George W. Mooney (1912). London: Longmans, Green. www.perseus.tufts.edu/hopper/text?doc=Perseus\%3atext\%3a1999.01. 0227 [01.12.2016].

Aratus Solensis (s. a.): Phaenomena. Edited by Mair, Gilbert Robinson (1921). London: William Heinemann; New York: G. P. Putnam's Sons. www.perseus.tufts.edu/hopper/ text?doc=Perseus\%3Atext\%3A2008.01.0483 [01.12.2016].

Eder, Maciej (2007): "How Rhythmical is Hexameter: A Statistical Approach to Ancient Epic Poetry". Digital Humanities 2007 Conference Abstracts, Second Edition. The University of Illinois, Urbana-Champaign: 50-52. hdl.handle.net/2142/2368 [10.09-2020].

Edwards, Mark W. (1986): "Homer and Oral Tradition: The Formula, Part I". Oral Tradition 1/2: 171-230.

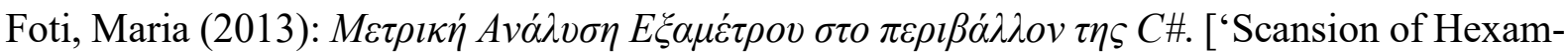
eter in the environment of C\#']. Unpublished postgraduate dissertation, National and Kapodistrian University of Athens and National Technical University of Athens.

Fusi, Daniele (2001): Automatic analysis of Greek epic hexameter. Unpublished doctoral dissertation, University of Genoa.

Fusi, Daniele (2002): 'L'esametro greco: leggi di Hermann e Lehrs". Paper presented at the international conference: L'esametro greco e latino: analisi, problemi e prospettive. Fisciano, University of Salerno.

Fusi, Daniele (2004): "Fra metrica e linguistica: per la contestualizzazione di alcune leggi esametriche”. In: Di Lorenzo, Enrico (ed.): L'esametro greco e latino: analisi, problemi e prospettive: 33-63). Atti del convegno di Fisciano, May 28-29, 2002. Napoli, Guida: $33-63$.

Fusi, Daniele (2008): “An Expert System for the Classical Languages: Metrical Analysis Components". Paper, held at the international conference: Trends in Computational and Formal Philology - An Italian Overview. Venice/Padua, May 22-24, 2008.

Fusi, Daniele (2015): “A Multilanguage, Modular Framework for Metrical Analysis: IT Patterns and Theorical Issues". Langages 199: 41-66.

Halporn, James W./Ostwald, Martin/Rosenmeyer, Thomas G. (1980): The Meters of Greek and Latin Poetry. Revised edition. Norman, OK: University of Oklahoma Press.

Hesiod (s. a.): Theogony. Internet Sacred Texts Archive: sacred-texts.com/cla/hesiod/ gtheo.htm [01.12.2016].

Hesiod (s. a.): Works and Days. Internet Sacred Texts Archive: sacred-texts.com/cla/hesiod/ works.htm [01.12.2016].

Homer (s. a.): Iliad. Internet Sacred Texts Archive: sacred-texts.com/cla/homer/greek/index .htm [01.12.2016].

Homer (s. a.): Odyssey. Internet Sacred Texts Archive: sacred-texts.com/cla/homer/greek/ index.htm [01.12.2016].

Jong, Jan R. De/Laan, Nancy M. (1996): “A Grammar for Greek Verse”. Research in Humanities Computing 4: 171-184. 
Kennedy, Jay B. (2010): “Plato’s Forms, Pythagorean Mathematics, and Stichometry”. Apeiron 43/1: 1-32.

Kennedy, Jay B. (2011): The Musical Structure of Plato's Dialogues. London: Routledge.

Laan, Nancy M. (1995): "Stylometry and Method: The Case of Euripides". Literary and Linguistic Computing 10/4: 271-278.

Latacz, Joachim (2010): Troja und Homer. Der Weg zur Lösung eines alten Rätsels (6 ${ }^{\text {th }}$ edition). München: Piper.

Maas, Paul (1962): Greek Metre. Oxford: Oxford University Press.

Mahoney, Anne (2003): "Talking About Meter in SGML". Computers and the Humanities 37/4: 469-473.

Mayrhofer, Colin M. (1987): "Scansion and Analysis of prakrit verses by text-processing programs". Revue Informatique et Statistique dans les Sciences humaines XXIII/1-4: 99-110.

Nonnus of Panopolis (s. a.): Dionysiaca (3 Vols.). Edited by: Rouse, Willian Henry D. (19401942). Cambridge, MA: Harvard University Press; London: Heinemann. www.perseus .tufts.edu/hopper/text?doc=Perseus:text:2008.01.0485 [01.12.2016].

Ott, Wilhelm (1973): "Metrical Analysis of Latin Hexameter". In: Zampolli, Antonio (ed.): Atti del convegno e della prima scuola internazionale. Florence, Italy: 379-390.

Papakitsos, Evangelos C. (1992): Automated Scansion of Classical Greek Verse. Unpublished postgraduate dissertation, The University of Liverpool.

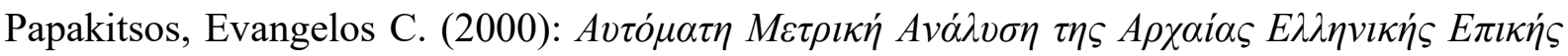
Пoí $\sigma \eta$ s. ['Automated Scansion of Ancient Greek Epic Poetry']. Athens: National Library of Greece.

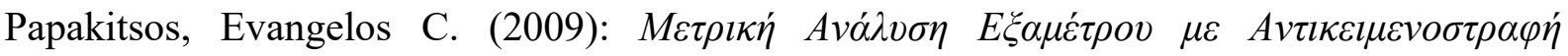

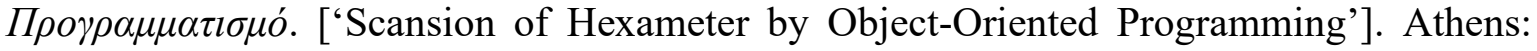
Thessalou.

Papakitsos, Evangelos C. (2011): “Computerized Scansion of Ancient Greek Hexameter”. Literary and Linguistic Computing 26/1: 57-69.

Papakitsos, Evangelos C./Tsoumaki, Maria I. (2013): "Relating Plato to the Pythagoreans: The Development of a Software System to Explore the Influence of the Pythagoreans on Plato's Work". International Journal of Literature and Art 1/1: 7-13.

Quintus Smyrnaeus (s. a.): Fall of Troy (Posthomerica). Edited by Arthur S. Way (1913). London: Heinemann/New York: G. P. Putnam's Sons. www.perseus.tufts.edu/hopper/text? doc $=$ Perseus:text:2008.01.0490 [01.12.2016].

Raven, David. S. (1962): Greek Metre. London: Faber \& Faber.

Seale, John Barlow (1830): An analysis of the Greek metres: for the use of students at the universities. 10th ed., carefully corrected. London: Printed for Whittaker.

Schadewaldt, Wolfgang (1975): Homer Ilias. Neue Übertragung von Wolfgang Schadewaldt $1^{\text {st }}$ edition. Frankfurt am Main: Insel.

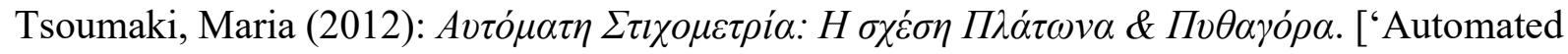
Stichometry: The relation between Plato \& Pythagoras']. Unpublished postgraduate dissertation, National and Kapodistrian University of Athens and National Technical University of Athens.

West, Martin L. (1982): Greek Metre. Oxford: Oxford University Press. 